\title{
ANALISIS KADAR FORMALIN DALAM DAGING AYAM DAN IKAN MENGGUNAKAN METODE KOLORIMETRI
}

\author{
Anne Yuliantini ${ }^{1^{*}}$, Lutfiah Sakiba ${ }^{2}$, Wendi Andriatna ${ }^{3}$ \\ 1. Program Studi Farmasi, Sekolah Tinggi Farmasi Bandung, Bandung-Indonesia \\ 2. Program Studi Farmasi, Sekolah Tinggi Farmasi Bandung, Bandung-Indonesia \\ 3. Program Studi Farmasi, Sekolah Tinggi Farmasi Bandung, Bandung-Indonesia
}

*Korespondensi: Anne Yuliantini | Sekolah Tinggi Farmasi Bandung | anne.yuliantini@stfb.ac.id

\begin{abstract}
Abstrak
Pendahuluan: Daging ayam dan ikan merupakan jenis pangan yang mudah membusuk jika tidak segera dimasak sehingga memungkinkan penjual menambahkan formalin kedalamnya agar lebih tahan lama. Berdasarkan Permenkes RI No. 033 Tahun 2012, formalin dilarang digunakan sebagai bahan tambahan pangan. Oleh karena itu, perlu dilakukan analisis formalin dalam daging ayam dan ikan yang beredar di salah satu pasar induk Kota Bandung.

Metode: Analisis formalin dilakukan dengan kolorimetri, yaitu mereaksikan formalin dengan asam kromatropat dan asam sulfat menghasilkan senyawa berwarna merah ungu yang dioptimasi dan divalidasi terlebih dahulu sebelum dilakukan analisis pada sampel.

Hasil: Menunjukkan bahwa metode kolorimetri ini optimum pada penambahan $0,5 \mathrm{~mL}$ asam kromatopat $0,5 \%$ dan $6 \mathrm{~mL}$ asam sulfat pekat yang diukur pada panjang gelombang maksimum $572 \mathrm{~nm}$, memberikan hasil batas deteksi dan kuantisasi berturut-turut sebesar 0,095 dan 0,316 bpj. Hasil perolehan kembali formalin dengan metode adisi pada sampel ikan dan ayam berturut-turut adalah sebesar 96,202-108,365\% dan 92,776-102,857\% dengan nilai standar baku relativ kurang dari $2 \%$ dari semua pengukuran.

Kesimpulan: Metode kolorimetri memenuhi persyaratan validasi dan dari hasil penggujian dengan metode ini ditemukan ada sampel ikan yang positif mengandung formalin dengan kadar 7,48 $\mu \mathrm{g} / \mathrm{g}$.
\end{abstract}

Kata Kunci: Asam Kromatropat, Daging ayam, Formalin, Ikan, Metode Kolorimetri.

Diterima 23 Mei 2019; Accepted 30 Juni 2019

\section{PENDAHULUAN}

Sumber protein hewani yang biasanya dikonsumsi oleh masyarakat diantaranya adalah daging ayam dan ikan. Daging ayam dan ikan termasuk jenis pangan yang mudah rusak (membusuk) sehingga memerlukan teknik pengawetan yang tepat. Cara pengawetan yang umum digunakan adalah dengan es. Teknik ini tidak praktis dan relatif mahal karena memerlukan jumlah es yang banyak. Hal ini mengakibatkan penjual menyalahgunakan bahan kimia untuk tujuan pengawetan. Salah satu bahan kimia yang sering disalahgunakan untuk pengawetan adalah formalin (Suryadi, 2010)

Penggunakan formalin sebagai bahan tambahan pangan dilarang digunakan di Indonesia sesuai dengan Permenkes RI No. 033 tahun 2012. Hal ini disebabkan karena konsumsi formalin dalam jangka panjang dapat memicu perkembangan sel-sel kanker dan berbahaya jika terhirup, tertelan atau mengenai kulit karena dapat mengakibatkan iritasi pada saluran pernapasan, reaksi alergi serta luka bakar (Saptarini, 2011).

Analisis formalin pada sampel makanan dapat dilakukan dengan beberapa metode, diantaranya metode kolorimetri (Altashuller et al., 1961; Nash, 1953), Spektrofotometri (Wang et al., 2007), KCKT (Li et al., 2007), dan kromatografi gas (Brianci et al., 2007).

Analisis menggunakan metode KCKT dan kromatografi gas memerlukan biaya yang relatif mahal dan instrumentasi yang rumit sehingga tidak cocok digunakan untuk analisis rutin yang mengutamakan analisis yang sederhana, cepat, ekonomis, dan sensitive (Suryadi, 2010). Metode yang digunakan pada penelitian ini adalah kolorimetri dengan pereaksi asam kromatropat karena telah diketahui bahwa analisis formalin dengan pereaksi Schyver memberikan stabilitas yang kurang baik (Sony, 2010).

Penelitian ini bertujuan untuk melakukan validasi metode analisis formalin pada daging ayam dan ikan dengan pereaksi asam kromatropat yang dioptimasi terlebih dulu yang selanjutkan digunakan untuk analisis formalin pada sampel daging ayam dan ikan yang dijual di Pasar Induk daerah Bandung.

\section{METODE}


Alat yang digunakan pada penelitian ini adalah mortar dan stemper, gelas ukur, labu ukur, beaker gelas, tabung reaksi, pipet ukur, pipet tetes, pipet volume, mikropipet, Erlenmeyer , batang pengaduk, karet hisap, timbangan digital, kuvet, dan spektrofotometer Uv-Vis. Bahan yang digunakan dalam penelitian ini diantaranya, formalin $37 \%$ pro analisis, aquades, asam kromatopat, dan asam sulfat pekat. Sampel daging ayam dan Ikan diperoleh dari Pasar Induk daerah Bandung yang dipilih secara acak dari penjual yang berbeda terdiri atas, ayam (A1, A2, A3), ikan kembung (B1, B2, B3), ikan salem (C1, C2, C3) dan ikan kerapu (D1, D2, D3).

\section{Penentuan Panjang Gelombang Maksimum}

Larutan formaldehid konsentrasi 3 bpj dimasukkan dalam tabung reaksi. Ditambahkan 0,5 mL larutan asam kromatopat dan $6 \mathrm{~mL}$ asam sulfat pekat. Diamati serapannya pada panjang gelombang 400-800 nm dengan alat spektrofotometer visibel hingga didapat panjang gelombang maksimum.

\section{Optimasi Metode}

Optimasi yang dilakukan meliputi penambahan asam kromatropat $0,5 \%(0,5 ; 1 ; 1,5 \mathrm{~mL})$, asam sulfat pekat $(3,4,5,6,7,8$,dan $9 \mathrm{~mL})$, dan waktu inkubasi, yaitu mengukur absorbansi mulai dari menit ke-0 sampai 30 pada panjang gelombang maksimum dengan spktrofotometri visibel.

\section{Pembuatan Kurva Kalibrasi}

Larutan formalin konsentrasi 2,5; 3; 3,5; 4; 4,5; dan 5 bpj dipipet $3 \mathrm{~mL}$ dan ditambahkan larutan asam kromatopat $0,5 \%$ sebanyak $0,5 \mathrm{~mL}$ dan $6 \mathrm{~mL}$ asam sulfat pekat. Didiamkan 15 menit pada suhu ruang, diamati serapannya pada panjang gelombang $572 \mathrm{~nm}$ dengan alat spektrofotometer visibel. Kemudian dibuat kurva kalibrasi hingga didapat persamaan linier $\mathrm{y}=\mathrm{bx}+\mathrm{a}$. Linieritas dari kurva dilihat dengan menghitung koefisien korelasi (r) dari persamaan garis regresi linier dan koefisien variansi regresi (Vx0).

Batas Deteksi (BD) dan Batas Kuantisasi (BK)

BD dan BK dihitung secara statistika dari persamaan kurva kalibrasi dengan perhitungan sebagai berikut :

$$
\mathbf{B D}=\frac{3 S y / x}{b} \quad \text { dan } \quad \mathbf{B K}=\frac{10 S y / x}{b}
$$

Keterangan:

Sy/x = Simpangan baku respon analit dari blanko

$\mathrm{b}=$ Slope persamaan garis

\section{$\underline{\text { Akurasi }}$}

Ditimbang sampel sebanyak 2,0 g dalam beaker gelas, kemudian ditambahkan $2 \mathrm{~mL}$ larutan formalin konsentrasi (3, 4, dan 5), kemudian didiamkan selama beberapa menit. Campuran tersebut ditambahkan kurang lebih $10 \mathrm{ml}$ aquadest, kemudian disaring. Filtrat yang diperoleh dipipet 3,0 $\mathrm{ml}$ dan ditambahkan asam kromotropat $0,5 \%$ sebanyak $0,5 \mathrm{~mL}$ dan asam sulfat pekat $6 \mathrm{~mL}$ kemudian didiamkan pada suhu ruang selama 15 menit, selanjutnya diukur serapannya pada panjang gelomabnag $572 \mathrm{~nm}$. Persen (\%) perolehan kembali dihitung dengan membandingkan konsentrasi yang diperoleh dengan konsentrasi sebenarnya.

\section{$\underline{\text { Presisi }}$}

Larutan formalin $4 \mathrm{ppm}$ dipipet sebanyak $2 \mathrm{~mL}$ ditambahkan kedalam beaker gelas yang berisi sampel, didiamkan beberapa menit kemudian disaring, filtrat diambil $3 \mathrm{~mL}$ dan ditambahkan 0,5 $\mathrm{mL}$ larutan asam kromotropat 0,5\% dan asam sulfat pekat $6 \mathrm{~mL}$ dalam tabung reaksi dan didiamkan pada suhu ruang selama 15 menit. Selanjutnya larutan diamati serapannya sebanyak 6 kali replikasi pada panjang gelombang 572 $\mathrm{nm}$.

\section{Penyiapan sampel}

Sampel daging ayam dan ikan difillet untuk dipisahkan antara daging dan tulang atau durinya, kemudian dipotong - potong kecil. Potongan sampel ditimbang 2 gram sampel dan dihaluskan, 
dimasukkan kedalam beaker gelas secara kuantitatif dengan bantuan kurang lebih $10 \mathrm{~mL}$ aquadest dan disaring.

\section{Uji Kualitatif Formalin dalam Sampel}

Masing-masing filtrat dari hasi penyiapan sampel sebanyak $3 \mathrm{~mL}$ dilakukan ditambahkan dengan 0,5 $\mathrm{mL}$ asam kromatopat $0,5 \%$ dan $6 \mathrm{~mL}$ asam sulfat pekat dan didiamkan selama 15 menit. Diamati perubahan warna yang terjadi jika terdapat warna merah ungu menandakan adanya formalin dalam sampel.

\section{Penetapan Kadar Formalin}

Sebanyak $3 \mathrm{~mL}$ filtrat ditambahkan $0,5 \mathrm{~mL}$ pereaksi asam kromotropat $0,5 \%$ dan $6 \mathrm{~mL}$ asam sulfat pekat pada labu ukur $10 \mathrm{~mL}$ digenapkan dengan akuades dan didiamkan selama 15 menit, kemudian diukur serapannya dengan dengan spektrofotometer visibel pada panjang gelombang maksimum.

\section{HASIL}

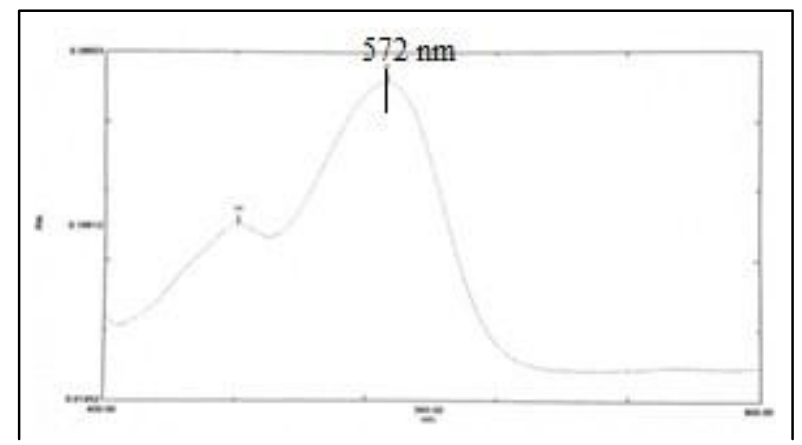

Gambar 1. Spektrum serapan formalin konsentrasi 3,5 bpj ditambah $0,5 \mathrm{~mL}$ asam kromatopat $0,5 \%$ dan 6 $\mathrm{mL}$ asam sulfat pekat pada panjang gelombang maksimum $572 \mathrm{~nm}$.

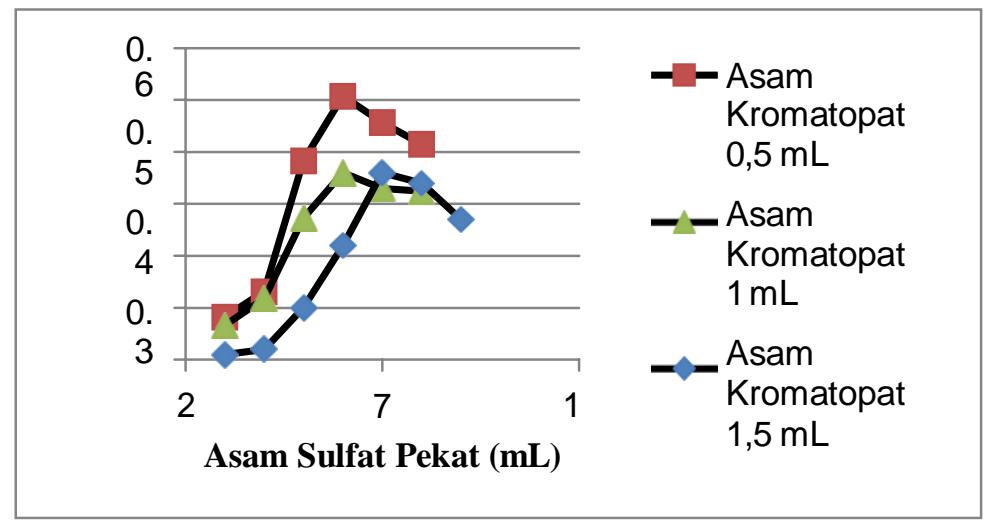

Gambar 2. Pengaruh penambahan asam kromatopat $0,5 \%(0,5 ; 1 ; 1,5 \mathrm{~mL})$ dan asam sulfat pekat $(3,4,5,6,7,8$, dan $9 \mathrm{~mL})$ terhadap absorbansi pada panjang gelombang $572 \mathrm{~nm}$

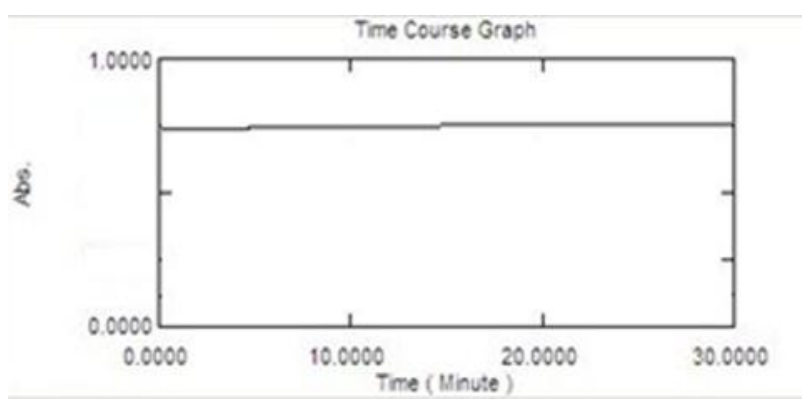

Gambar 3. Absorbansi hasil reaksi formalin konsentrasi 3,5 bpj ditambah $0,5 \mathrm{~mL}$ asam kromatopat $0,5 \%$ dan $6 \mathrm{~mL}$ asam sulfat pekat pada panjang gelombang maksimum $572 \mathrm{~nm}$ dari menit ke-0 sampai 30. 


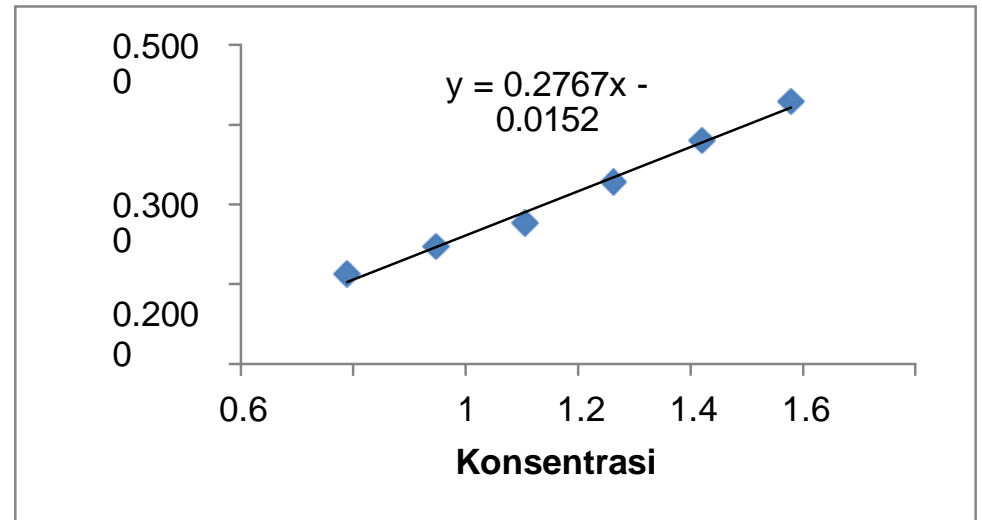

Gambar 4. Kurva kalibrasi formalin yang telah direaksikan dengan $0,5 \mathrm{~mL}$ asam kromatopat $0,5 \%$ dan 6 $\mathrm{mL}$ asam sulfat pekat pada panjang gelombang $572 \mathrm{~nm}$

Tabel 1 Hasil Uji Akurasi dan Presisi

\begin{tabular}{cccc}
\hline $\begin{array}{c}\text { Konsentrasi Yang Diperoleh } \\
(\boldsymbol{\mu} \mathbf{g} / \mathbf{m L})\end{array}$ & Konsentrasi Teoritis & Perolehan Kembali $(\boldsymbol{\%})$ & SBR $(\boldsymbol{\%})$ \\
\hline 0,152 & & 96,202 & \\
0,164 & 0,158 & 103,797 & \\
0,165 & & 104,403 & 1,9078 \\
\hline 0,209 & & 99,524 & \\
0,211 & 0,210 & 100,476 & 1,2060 \\
0,206 & & 98,095 & \\
\hline 0,285 & & 108,365 & \\
0,279 & 0,263 & 106,084 & 1,2241 \\
\hline 0,285 & & 108,365 & \\
\hline
\end{tabular}

Tabel 2 Uji Kualitatif Sampel Daging Ayam dan Ikan

\begin{tabular}{|c|c|c|c|}
\hline Sampel & Kode & Uji Kualitatif & Kadar formalin $(\mu \mathrm{g} / \mathrm{g})$ \\
\hline \multirow{3}{*}{ Ayam } & $\mathrm{A} 1$ & - & $\mathrm{TD}$ \\
\hline & $\mathrm{A} 2$ & - & $\mathrm{TD}$ \\
\hline & A3 & - & $\mathrm{TD}$ \\
\hline \multirow{3}{*}{ Ikan kembung } & $\mathrm{B} 1$ & - & $\mathrm{TD}$ \\
\hline & $\mathrm{B} 2$ & - & TD \\
\hline & B3 & + & 7,48 \\
\hline \multirow{3}{*}{ Ikan salem } & $\mathrm{C} 1$ & - & $\mathrm{TD}$ \\
\hline & $\mathrm{C} 2$ & - & $\mathrm{TD}$ \\
\hline & $\mathrm{C} 3$ & - & TD \\
\hline \multirow{3}{*}{ Ikan Kerapu } & D1 & - & $\mathrm{TD}$ \\
\hline & $\mathrm{D} 2$ & - & $\mathrm{TD}$ \\
\hline & D3 & - & TD \\
\hline
\end{tabular}

Keterangan : (-) tidak menghasilkan warna ungu (+)menghasilkan warna ungu TD : tidak terdeteksi

\section{PEMBAHASAN}

Penyalahgunaan formalin sebagai pengawet pangan sering ditemukan di Indonesia meskipun pemerintah telah melarangnya. Oleh karena itu, perlu dilakukan analisis rutin pada makanan yang rentan ditambahkan formalin guna menjaga kualitas dan keamanan makanan yang beredar dan dikonsumsi 
masyarakat (Suryadi, 2010).

Analisis formalin dapat dilakukan dengan beberapa metode, salah satunya kolorimetri yang diukur dengan spektrofotometer visibel. Formalin tidak dapat diukur secara langsung dengan spektrofotometer uv - vis karena tidak memiliki gugus kromofor yang menyerap pada panjang gelombang UV-vis. Agar dapat dianalisis secara spektrofotometri, formalin direaksikan dengan pereaksi geser untuk membentuk senyawa yang menyerap pada panjang gelombang uv-visibel (Silvana, 2015). Pereaksi geser yang biasanya digunakan untuk analisis formalin adalah Schryver, Nash, dan asam kromatropat (Mauliddya, 2016).

Pada penelitian ini, pereaksi yang digunakan untuk analisis formalin dalam daging ayam dan ikan adalah asam kromatropat. Formalin dapat dianalisis dengan menggunakan pereaksi asam kromatropat dalam suasana asam kuat menghasilkan senyawa kompleks yang berwarna merah keunguan (Letourneau \& Krog, 1952; Fagnani, 2003). Reaksi ini spesifik untuk formaldehid dan tidak dihasilkan pada reaksi dengan senyawa aldehid dan senyawa karbon lain, seperti keton dan asam karboksilat. Reaksi yang terjadi antara formalin dan asam kromatopat dalam suasana asam kuat berjalan secara substitusi pada posisi para. Dimana reaksi tersebut menghasilkan senyawa para quinoidal yang berwarna ungu (Fagnani et al., 2002), dengan reaksi sebagai berikut :

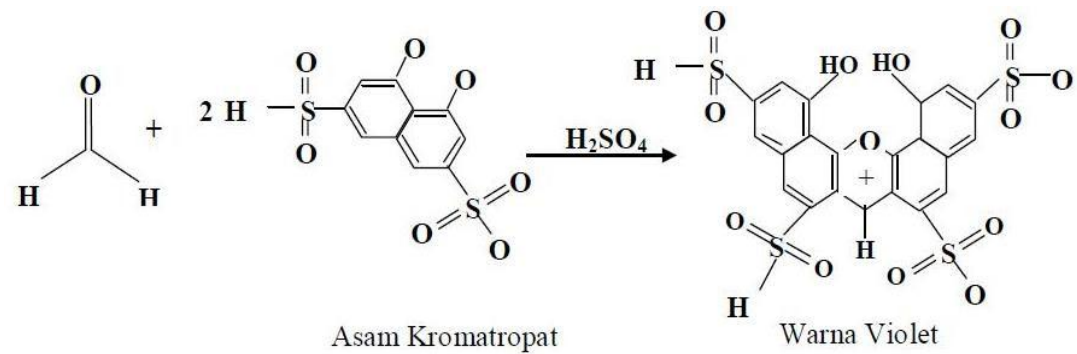

Gambar 5 Reaksi Formaldehid dan asam kromatropat yang membentuk senyawa berwarna ungu

Hasil reaksi formalin dan asam kromatropat diukur dengan spektrofotometer visibel dan dilakukan penelusuran panjang gelombang maksimum pada 400-800 $\mathrm{nm}$. Panjang gelombang maksimum yang didapat sebesar $572 \mathrm{~m}$ sesuai dengan spektrum yang dapat dilihat pada Gambar 1 sedangkan panjang gelombang maksimum pustaka sebesar $580 \mathrm{~nm}$. Perbedan ini dapat disebabkan oleh alat, bahan, serta kondisi pengukuran yang berbeda.

Optimasi penambahan pereaksi asam kromatopat dan asam sulfat pekat pada larutan standar formalin dilakukan untuk menentukan kondisi optimum reaksi. Hasil optimasi dapat dilihat pada Gambar 2. Dari beberapa variasi jumlah pereaksi yang ditambahkan, didapatkan bahwa kondisi optimum didapat dari penambahan $0,5 \mathrm{~mL}$ asam kromatopat $0,5 \%$ dengan $6 \mathrm{~mL}$ asam sulfat pekat yang didasarkan dari nilai absorbansi tertinggi yang dihasilkan dari campuran pereaksi asam kromatropat dan asam sulfat pekat.

Setelah itu, dilakukan penentuan waktu inkubasi bertujuan untuk menentukan waktu pengukuran saat absorbansi yang dihasilkan konstan atau stabil, tidak dipengaruhi oleh waktu analisis (Tuliandi et al., 2015). Hasil pengukuran waktu inkubasi dapat dilihat pada Gambar 3 yang menunjukkan bahwa absorbansi yang diukur dari menit ke-15 sampai 30 konstan atau stabil sehingga waktu pengukuran dapat dilakukan setelah 15 menit direaksikan.

Kondisi optimum yang sudah didapatkan divalidasi dengan mengukur beberapa parameter validasi, yaitu linieritas, batas deteksi dan kuantisasi, presisi, dan akurasi (Harmita, 2004). Parameter linieritas dapat dilihat di Gambar 4, yaitu dari pembuatan kurva kalibrasi dengan menghitung nilai kofisien korelasi (r) sebesar 0,994 dan nilai Vx0 sebesar 0,74\%, dengan persamaan kurva kalibrasi y $=0,276 \mathrm{x}-0,01567$. Dari persamaan regresi kurva kalibrasi, dihitung nilai batas deteksi dan kuantisasi berturut-turut sebesar 0,094883 dan $0,316278 \mathrm{bpj}$, sehingga dalam penentuan kadar formalin yang dapat dianalisis secara kuantitatif harus lebih besar atau sama dengan 0,316278 bpj (sesuai batas kuantisasi yang didapat).

Uji akurasi bertujuan untuk menentukan tingkat ketepatan mutu metode yang dilakukan dengan cara membandingkan konsentrasi sampel setelah adisi dengan konsentrasi standar dalam sampel tertentu. Dari hasil percobaan pada sampel ikan dan ayam berturut-turut adalah sebesar 96,202- 108,365\% dan 92,776102,857 sesuai dengan Tabel 1. Hasil uji perolehan kembali yang memenuhi syarat adalah $80-110 \%$, dengan demikian dapat dikatakan bahwa metode ini mempunyai ketelitian yang baik. 
Uji presisi pada daging ayam dan daging ikan dengan masing- masing dilakukan presisi secara berulang (repeatability) adalah ketelitian yang diperoleh dari hasil pengulangan dengan menggunakan metode, operator, peralatan, laboratorium, dan dalam interval pemeriksaan waktu yang singkat dan presisi antara (Intermediate Precision).Presisi antara merupakan bagian dari presisi yang dilakukan dengan cara mengulang pemeriksaan terhadap contoh uji dengan alat, waktu, analis yangberbeda, namun dalam laboratorium yang sama. Pemeriksaan keterulangan bertujuan untuk mengetahui konsistensi analit, tingkat kesulitan metode dan kesesuaian metode. Kedua hasil presisi didapatkan nilai \% RSD yang memenuhi persyaratan yakni kurang dari $2 \%$.

Setelah metode dinyatakan valid dengan terpenuhinya syarat parameter validasi, dilakukan analisis pada sampel daging ayam dan ikan yang telah diambil dari salah satu Pasar Induk daerah Bandung secara acak. Sampel yang digunakan memiliki ciri-ciri fisik sampel yang diduga mengandung formalin, antara lain strukturnya yang kenyal, putih bersih dan tidak dihinggapi lalat.

Tahap pertama sampel diuji secara kualitatif dilihat dari perubahan warna ketika sampel direaksikan dengan pereaksi asam kromatopat dalam suasana asam kuat, dari beberapa sampel hanya satu sampel yang menunjukkan positif secara kualitatif yakni sampel ikan kembung. Untuk menentukan kadar yang terkandung dalam sampel maka dilakukan analisis kuantitatif dengan spektrofotometri visibel.

Pemeriksaan sampel ikan secara kuantitatif memberikan serapan sebesar 0,705 setelah dihitung didapat berat formalin dalam sampel sebesar $7,48 \mu \mathrm{g} / \mathrm{g}$. Hasil ini menunjukkan bahwa sampel mengandung formalin yang cukup tinggi. Hal ini tentu tidak sesuai dengan permenkes RI no 33 tahun 2012 yang telah melarang penggunaan formalin sebagai bahan tambahan pangan, kadar tersebut juga jauh dari nilai TDI atau Asupan maksimum harian yang dapat ditoleransi atau Maximum Torelable Daily Intake yang selanjutnya disingkat MTDI adalah jumlah maksimum suatu zat dalam milligram per kilogram berat badan yang dapat dikonsumsi dalam sehari tanpa menimbulkan efek merugikan terhadap kesehatan. Tertera dalam codex alimentarius commission yang dikeluarkan WHO tahun 2013 menyatakan bahwa nilai TDI formalin sebesar $0,15 \mathrm{mg} / \mathrm{Kg}$. Walaupun telah banyak dilakukan sidak oleh lembaga pemerintahan ternyata tidak dapat dipungkuri bahwa penggunaan formalin masih tetap banyak disalahgunakan sebagai bahan pengawet.

\section{KESIMPULAN}

Kesimpulan yang didapat antara lain:

1. Metode kolorimetri untuk analisis formalin optimum saat penambahan $0,5 \mathrm{~mL}$ asam kromatopat $0,5 \%$ dan $6 \mathrm{~mL}$ asam sulfat pekat dengan waktu inkubasi stabil hingga 30 menit.

2. Dari 12 sampel baik pada daging ayam, ikan salem, ikan kembung dan ikan kerapu pengujian secara kualitatif menunjukkan satu sampel yang positif mengandung formalin, hasil uji kualitatif ini dilanjutkan dengan penetapan kadar menggunakan metode kolorimetri dengan spektrofotometri visibel.

3. Analsisis Kuantitatif dari ikan kembung di pasar induk daerah Bandung didapatkan kadar 7,48 $\mu \mathrm{g} / \mathrm{g}$, hasil yang diperoleh cukup tinggi dan telah melebihi batas Torelable Daily Intake .

\section{REFERENSI}

Altshuller A.P., Miller D. L., SlevaS.F., 1961. Determination of formaldehyde in Gas Mixture by the Chromotropic Acid Method. Anal Chem., 33(4), 621-625.

Brianci F., et al., 2007. Fish and Food Safety: Determination of Formaldehyde in 12 Fish Species by SPME Extraction and GC- MS Analysis. Food Chem., 100: 1049-1053.

Fagnani, E., Melios, C.B., Pezza, L., Pezza, H.R. 2003. Chromotropic acid/formaldehid reaction in strongly acidic media. The role of dissolved oxygen and replacement of concentrated sulphuric acid. Talanta, Vol. 60, p. $171-176$.

Harmita. (2004). Review Artikel Petunjuk Pelaksanaan Validasi Metode dan Cara Perhitungan. Jurnal Majalah Ilmu Kefarmasian, Departemen Farmasi : FMIPA UI, Vol,1, No.3.

Letourneau, Duane, dan Krog, Norman, 1952. The Use of Chromotropic Acid for The Quantitative Determination of 2,4- Dichlorophenoxy-acetic Acid. Scientific Journal Series of the Minnesota Agricultural Experiment Station, No 2817, hal. 822-823.

Li J., Zhu J, Ye L., 2007. Determination of Formaldehyde in Squid by HPLC. Asia Pac. J. Clin. Nutr., 16(1): $127-130$. 
Mauliddya Nuryatin dkk, 2016. Analisis Formalin dalam Daging Ayam menggunakan Metode Spektrofotometri UV-visibel. Prosiding Farmasi. Vol 2. No.1, 97-105, ISSN : 2460-6472.

Nash T., 1953. Colorimetric Estimation of Formaldehyde by Means of Hantzch Reaction. Biochem.J., 55(3), 417-418.

Saptarini, M, N. Wardati, Y. Supriatna, U. 2011. Deteksi Formalin Dalam Tahu Di Pasar Tradisional Purwakarta. Jurnal Penelitian Sains \& Teknologi. 1(2). 37-44.

Silvana Chichilia U., dkk., 2015. Validasi Metode Analisis Formalin dala Daging Paha Ayam di Kota Manado. Pharmacon Jurnal Ilmiah Farmasi-UNSRAT, Vol.4 No.3, 139-146.

Sony Satria W., 2011. Analisis Formalin dalam Ikan dan Udang Segar dengan Pereaksi Schryber yang Dimodifikasi.Sripsi S1 FMIPA, Farmasi UI.

Suryadi Herman, dkk., 2010. Analisis Formalin dalam Sampel Ikan dan Udang Segar dari Pasar Muara Angke. Jurnal Majalah Ilmu Kefarmasian, Departemen Farmasi : FMIPA UI, Vol,7, No.3.16-31.

Tuliandi, G, P. Sudewi, S. Lolo, W, A. (2015). Validasi Metode Analisis Untuk Penetapan Kadar Parasetamol dalam Sediaan Tablet Secara Spektrofotometri Ultraviolet. Jurnal Ilmiah Farmasi. ISSN 2302-2493. 4. 168-178.

Wang S., Cui X., Fan G., 2007. Rapid Determination of Formaldehyde and Sulfur Dioxide in Food Products and Chinese Herbals. Food Chem., 103: 1487-1493. 